\title{
New Cohort of Patients With CEDNIK Syndrome Expands the Phenotypic and Genotypic Spectra
}

Annelise Y. Mah-Som, MD, PhD, Cristina Skrypnyk, MD, PhD, Andrea Guerin, MD, FRCPC, FCCMG, Raafat Hammad Seroor Jadah, MBBCh, AB Ped, SB Ped, Vinayak Nivrutti Vardhan, MBBS, DCH, Robert C. McKinstry, MD, PhD, and Marwan S. Shinawi, MD

Neurol Genet 2021;7:e553. doi:10.1212/NXG.0000000000000553

\section{Abstract}

\section{Objective}

To report 6 new patients with cerebral dysgenesis, neuropathy, ichthyosis, and keratoderma (CEDNIK) syndrome.

\section{Methods}

Clinical exome or targeted sequencing were performed to elucidate the molecular genetic cause in patients with neurocognitive abnormalities and brain imaging findings.

\section{Results}

CEDNIK syndrome is a rare genetic condition caused by biallelic pathogenic loss-of-function variants in synaptosomal-associated protein 29 (SNAP29), which encodes a vesicular membrane fusion protein. Clinical manifestations include significant developmental delay/ intellectual disability (DD/ID), brain abnormalities, failure to thrive, and skin abnormalities. To date, 19 patients from 10 unrelated families with CEDNIK syndrome have been reported. We report 5 additional patients with homozygous predicted loss-of-function variants in SNAP29 and one with compound heterozygous variants: a frameshift SNAP29 variant and a $370 \mathrm{~kb}$ deletion on 22q11.2. All patients exhibit DD/ID, ichthyosis and/or palmoplantar keratoderma, and hypotonia. Four of 6 subjects had hypomyelinated white matter on MRI, 2 of 6 had early puberty, and 4 of 6 had strabismus, which were previously rarely reported. Other phenotypes were variably present, including dysmorphic features, feeding difficulties, and recurrent respiratory infections. The cohort includes 2 siblings with a c.2T $>C$ variant who have a relatively milder phenotype, a patient with the most $\mathrm{C}$-terminal variant yet described (c.622G $>$ T), and 3 patients with previously described variants (c.354dupG, c.487dupA).

\section{Conclusions}

This cohort of 6 additional patients expands the genotypic and phenotypic spectrum of CEDNIK syndrome, highlighting previously under-recognized features such as hypomyelination, seizures, and early puberty. Owing to reduced penetrance of the skin phenotype, cerebral dysgenesis, and neuropathy, we propose renaming this syndrome SNAP29-related disorder.
Correspondence

Dr. Shinawi

mshinawi@wustl.edu 


\section{Glossary}

CMA = chromosomal microarray analysis; DD = developmental delay; ID = intellectual disability; NMD = nonsense-mediated mRNA decay; OFC = occipitofrontal circumference; PMG = polymicrogyria; PMLD = Pelizaeus-Merzbacher-like disorder; SNAP29 = synaptosomal-associated protein 29.

Cerebral dysgenesis, neuropathy, ichthyosis, and keratoderma (CEDNIK) syndrome (MIM\# 609528) was first described by Sprecher et al. ${ }^{1}$ in 2005 , and to date, 19 individuals from 10 unrelated families have been described. ${ }^{2-9}$ This is a rare autosomal recessive disease caused by loss-of-function variants in synaptosomal-associated protein 29 (SNAP29). SNAP29 is involved in membrane fusion processes including exocytosis, endocytosis, autophagy, and ciliogenesis. In human skin and animal models, loss of SNAP29 leads to abnormal maturation, spatial organization, and differentiation of epidermal layers, neurons, and muscle fibers. ${ }^{1,10-13}$

CEDNIK syndrome is characterized by severe neurologic abnormalities leading to global developmental delay, hypotonia, and neuropathy as well as dermatologic abnormalities (ichthyosis and keratoderma). Typical MRI findings are hypoplasia/dysplasia of the corpus callosum and polymicrogyria (PMG). Congenital hypotonia leads to feeding difficulties, failure to thrive, and development of limb spasticity. Individuals with CEDNIK syndrome meet few developmental milestones and often have vision or hearing loss. Most patients have dysmorphic facial features without a recognizable gestalt. Prognosis is poor; the eldest patient was 13 year old at publication, and 4 patients died of pneumonia between ages 5 and $12 .{ }^{1,8}$

Here, we describe 6 additional patients with CEDNIK syndrome from 5 unrelated families, one of whom is older than any previous patient described. Their genotypes include a novel C-terminal predicted pathogenic variant in SNAP29 and a variant previously associated with Pelizaeus-Merzbacher-like disorder (PMLD). ${ }^{7}$

\section{Methods}

\section{Standard Protocol Approvals, Registrations, and Patient Consents}

Written informed consent and authorization for publication was received from patients' guardians. The Washington University in St. Louis Media Authorization for the Use and Disclosure of Protected Health Information form was used for all patients except patient 4, who used the Kingston General Hospital Consent for Photography form.

\section{Genetic Testing}

Next-generation sequencing was performed at each institution on a clinical basis for evaluation of specific findings (see also Supplementary Material-B). For patients 1 and 4, trio exome sequencing was performed through GeneDx (Gaithersburg, MD). Patient 2 had targeted testing (GeneDx) for the familial pathogenic variant previously found in his sister. For patient 3, a chromosomal microarray analysis (CMA) was performed at Children's Hospital Los Angeles. An XomeDxSlice (GeneDx) was performed to sequence candidate genes SNAP29 and PEX7. Patient 5 had a CMA, followed by exome sequencing by Genome Diagnostics (Nijmegen, The Netherlands). Patient 6 had exome sequencing by Mendelics (Sao Paolo, Brazil).

\section{Clinical History}

Clinical history was obtained from chart review and/or discussion with the patient's parents. Growth and occipitofrontal circumference (OFC) percentiles refer to World Health Organization charts for $\leq 2$ years of age and Centers for Disease Control Prevention charts for $>2$ years.

\section{Statistics}

"N-1" $\chi^{2}$ test with 2-tailed $p$ value (medcalc.org) was used to compare proportions between groups.

\section{Data Availability}

Anonymized data will be shared by request from any qualified investigator.

\section{Results}

\section{Molecular Results}

Table 1 and figure 1A diagram shows the SNAP29 variants in the 6 patients in this cohort compared with previously reported cases.

Patients 1 and 2 are homozygous for a c.2T>C variant in SNAP29. This is predicted to alter the initiation codon with uncertain protein product (p.Met1?) and was previously reported as a compound heterozygous variant in a patient with PMLD. ${ }^{7}$

Patient 3 has a region of homozygosity detected by CMA at chromosome 22q11.2 encompassing 32 OMIM genes. Targeted testing revealed a homozygous frameshift pathogenic variant (c.354dupG; p.Leu119Alafs*15) in SNAP29, which was previously associated with CEDNIK syndrome. ${ }^{6}$

Patient 4 has a homozygous c.622G $>\mathrm{T}$; p.Glu208* nonsense variant in the last exon of SNAP29. This variant is the most C-terminal yet described. In addition, CMA showed a 1.22 $\mathrm{Mb}$ duplication of unclear clinical significance at $8 \mathrm{p} 23.2$ containing CSMD1, deletions of which have been associated with head and neck cancers. ${ }^{14}$ 
Table 1 SNAP29 Mutations Described to Date

\begin{tabular}{|c|c|c|c|c|}
\hline Ref. & $\mathbf{N}$ & Ethnicity & SNAP29 variant & Predicted protein change \\
\hline \multirow[t]{2}{*}{1} & 6 sibs & Arab & c.223delG & p.Val75Serfs $* 28$ \\
\hline & 1 & Arab & c.223delG & p.Val75Serfs $\star 28$ \\
\hline 2 & 2 sibs & Kashmiri Pakistani & c.487dupA & p.Ser163Lysfs*6 \\
\hline 3 & 2 sibs & Jordanian & c.223delG & p.Val75Serfs*28 \\
\hline 4 & 1 & Jordanian & c. $85 \mathrm{C}>\mathrm{T}$ & p.Arg29* \\
\hline 5 & 1 & Indian & c. $253 C>T$ & p.Arg85* \\
\hline 6 & 1 & N/A & c.354dupG & p.Leu119Alafs*15 \\
\hline 7 & 1 & Caucasian, Hispanic & c.2T>C, c.354dupG & p.Met1?; p.Leu119Alafs*15 \\
\hline \multirow[t]{2}{*}{8,9} & 3 sibs & Pakistani & c.487dupA & p.Ser163Lysfs*6 \\
\hline & 1 & Pakistani & c.487dupA & p.Ser163Lysfs*6 \\
\hline \multirow[t]{4}{*}{16} & 1 & N/A & c.388insGA, $\Delta 22 q 11.2$ & p.Thr130Argfs*17 \\
\hline & 1 & N/A & c.28delCCGTT, $\Delta 22 q 11.2$ & p.Pro 10 Argfs $* 42$ \\
\hline & 1 & N/A & c. $265 \mathrm{G}>\mathrm{A}, \Delta 22 \mathrm{q} 11.2$ & p.Glu89Lys \\
\hline & 1 & N/A & c. $268 \mathrm{C}>\mathrm{T}, \Delta 22 \mathrm{q} 11.2$ & p.Arg90Cys \\
\hline \multirow[t]{5}{*}{ This paper } & 2 sibs (Pts 1, 2) & Amish, Mennonite & c. $2 \mathrm{~T}>\mathrm{C}$ & p.Met1? \\
\hline & $1(\mathrm{Pt} 3)$ & Hispanic Mexican & c.354dupG & p.Leu119Alafs*15 \\
\hline & $1(\mathrm{Pt} 4)$ & Tibetan, Indian & c. $622 \mathrm{G}>\mathrm{T}$ & p.Glu208* \\
\hline & 1 (Pt 5) & Arab & c.487dupA & p.Ser163Lysfs*6 \\
\hline & 1 (Pt 6) & Brazilian & c.354dupG, 370kb deletion & p.Leu119Alafs*15 \\
\hline
\end{tabular}

Notation per Human Genome Structural Variation Consortium 2016 guidelines.

* Indicates stop codon, fs*\# indicates frame shift producing \# mutated amino acids (including the stop codon), ? indicates unknown product, $\Delta$ indicates microdeletion leading to $22 q 11.2$ deletion syndrome. Patients are homozygous for variant listed unless 2 variants listed. Please note that Sprecher et al. ${ }^{1}$ refer to c.223delG in their publication as c.220delG as they started numbering after the initiation codon.

Patient 5 has a homozygous, previously described pathogenic frameshift variant in SNAP29 designated c.487dupA; p.Ser163Lysfs ${ }^{*} 6$. Cell culture experiments suggest that the mutated protein is produced at normal levels with abnormal localization. $^{2}$

Patient 6's exome sequencing revealed a heterozygous c.354dupG; pLeu119Alafs* 15 mutation in SNAP29 and an approximately $370 \mathrm{~kb}$ deletion in $22 \mathrm{q} 11.2$ encompassing 4 OMIM genes (SNAP29, PI4KA, SERPIND1, and LZTR1). Biallelic PI4KA variants in 3 unborn fetuses were associated with PMG, cerebellar hypoplasia, and arthrogryposis (MIM $\# 616531){ }^{15}$ but no variants in PI4KA were detected in patient 6.

\section{Case Reports}

\section{Patient 1}

Patient 1 is a 19-year-old woman of mixed Amish and Mennonite heritage whose parents estimate they are fifth cousins (figure 1B). Pregnancy was complicated by maternal malarial infection, but she was born at full-term without significant complications.

Patient 1 had no significant health problems in her first year of life. She was late to walk (24 months) and talk (2-3 years). She developed seizures at the age of 4; EEG showed multifocal epileptiform discharges. Repeat EEG at the age of 8 showed discharges in the left occipital and bilateral temporal regions. Seizures stopped on antiepileptic medication by the age of 10 . She had premature thelarche with breast development at the age of 7 , but menstruation began at the age of 9. She lost motor and speech milestones at the age of 12-13. She uses a wheelchair but walks with assistance. She knows few words, and her speech is dysarthric. She is hyperopic and required 3 corrective surgeries for strabismus. She exhibits constipation.

On physical examination at the age of 18 , her height, weight, and OFC were $<1$ st, 22nd, and 40th percentile, respectively. She has mild hypotelorism, a round face, and slightly deepset eyes (figure 2A). Dermatologic findings include mild 

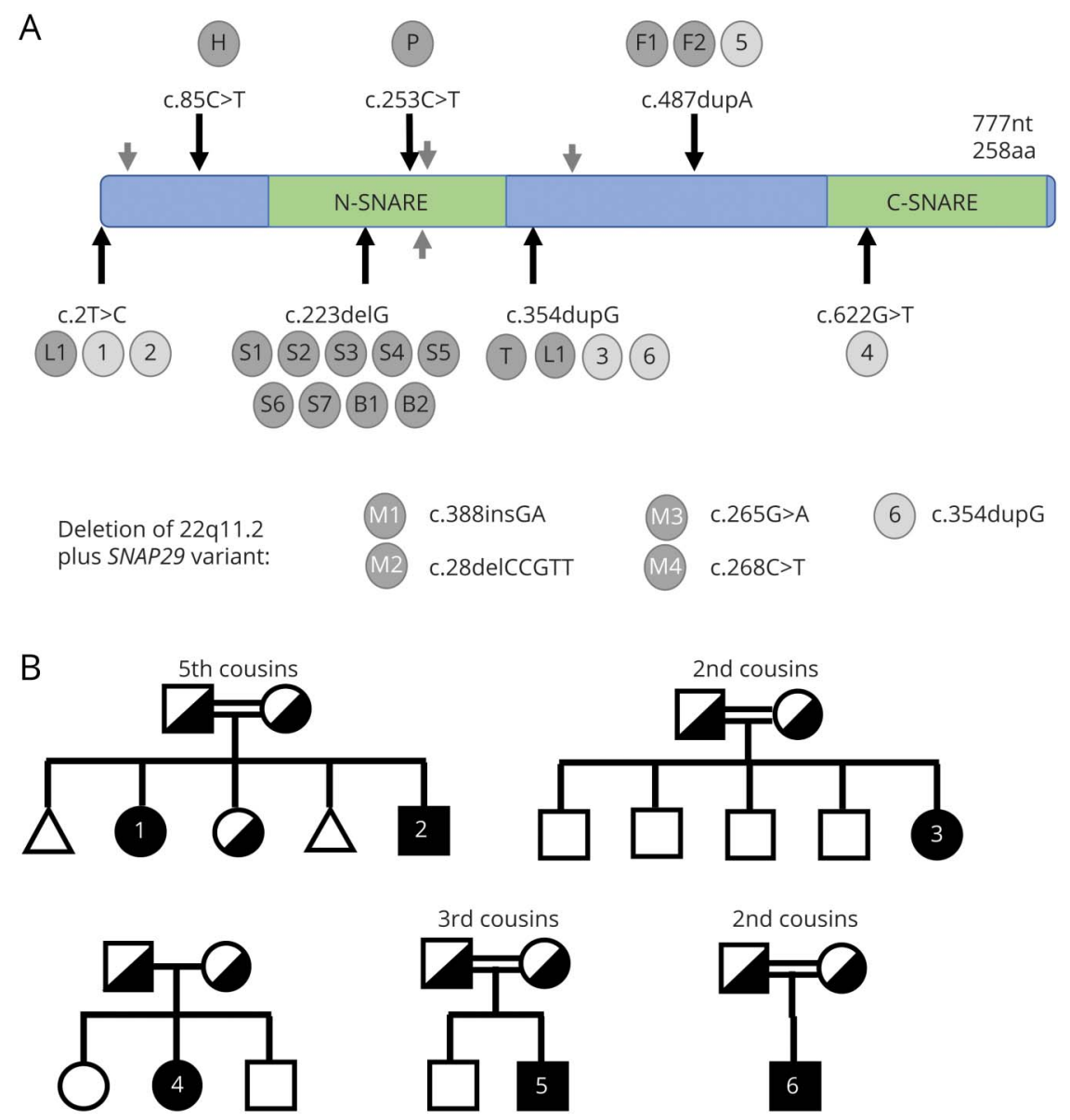

(A) SNAP29 variants shown by cDNA position and nucleotide change with notations per Human Genome Structural Variation Consortium 2016 guidelines. Listed next to each variant are associated cases, noted as labelled gray circles. Labels \#1-6 (light gray) indicate patients reported in this manuscript. Lettered labels indicate cases reported by previous reports (dark gray), noted by the first author's last initial. Please note, all patients carry homozygous variants except L1 (compound heterozygous), ${ }^{7}$ M1-4 (hemizygous, gray arrows), ${ }^{16}$ and patient 6 (hemizygous). (B) Patient pedigrees. Symbol key: =consanguineous marriage, circle: female, square: male, triangle: miscarriage, filled: affected (numbers refer to subjects in this cohort), half-filled: known asymptomatic carrier. Note both miscarriages were first trimester and did not undergo genetic testing. CDNA = complementary DNA; CEDNIK = cerebral dysgenesis, neuropathy, ichthyosis, and keratoderma; SNAP29 = synaptosomal-associated protein 29.

ichthyosis on her limbs and palmoplantar keratoderma (figure 2B). Examination revealed truncal hypotonia, lower extremity hypertonia/clonus with hamstring tightness, and scoliosis.

\section{Patient 2}

Patient 2 is a 13-year-old boy and the youngest sibling of patient 1 (figure 1B). He was delivered at term after an uncomplicated pregnancy and required oxygen supplementation for 2 hours for respiratory distress.

Patient 2 had no significant health problems as an infant. He had a seizure at the age of 3 but did not require antiepileptics and had a normal EEG. His DD is less severe than patient 1's; he sat without support and crawled at $7 \mathrm{mo}$, walked at $18 \mathrm{mo}$, and can run, jump, and ride a bike with training wheels. He can trace words, count to 13 , and speaks in short sentences with some dysarthria and a significant stutter. He had one surgery for strabismus and wears glasses for hyperopia. His pubertal development has been normal.

On physical examination at the age of 12, patient 2's height, weight, and OFC were normal. His facial features are similar to his sister's, with more severe dermatological involvement including wide-spread ichthyosis and keratoderma of his soles (figure e-1, links.lww.com/NXG/A366). Examination showed truncal hypotonia, lower extremity hypertonia with tight hamstrings, hyperreflexia, and a dragging wide-based gait.

\section{Patient 3}

Patient 3 is a 9-year-old girl of Hispanic Mexican descent whose parents estimate they are second cousins. The proband was the mother's fifth pregnancy; her 4 older brothers are healthy, although one has $\mathrm{ADHD}$ (figure 1B).

At birth, patient 3 had difficulty feeding and received a G-tube at the age of 2 for failure to thrive. She was diagnosed with cerebral palsy with spastic diplegia. Breast development started at the age of 8 (early normal). She has global DD; at 9 years, she can sit, crawl, walk for 1 minute with assistance, and speaks one 2-word phrase. She has been hospitalized for recurrent pneumonia and bronchiolitis. She received corrective surgery for strabismus. She takes levothyroxine for hypothyroidism, gabapentin for spasticity, and laxatives for constipation. 

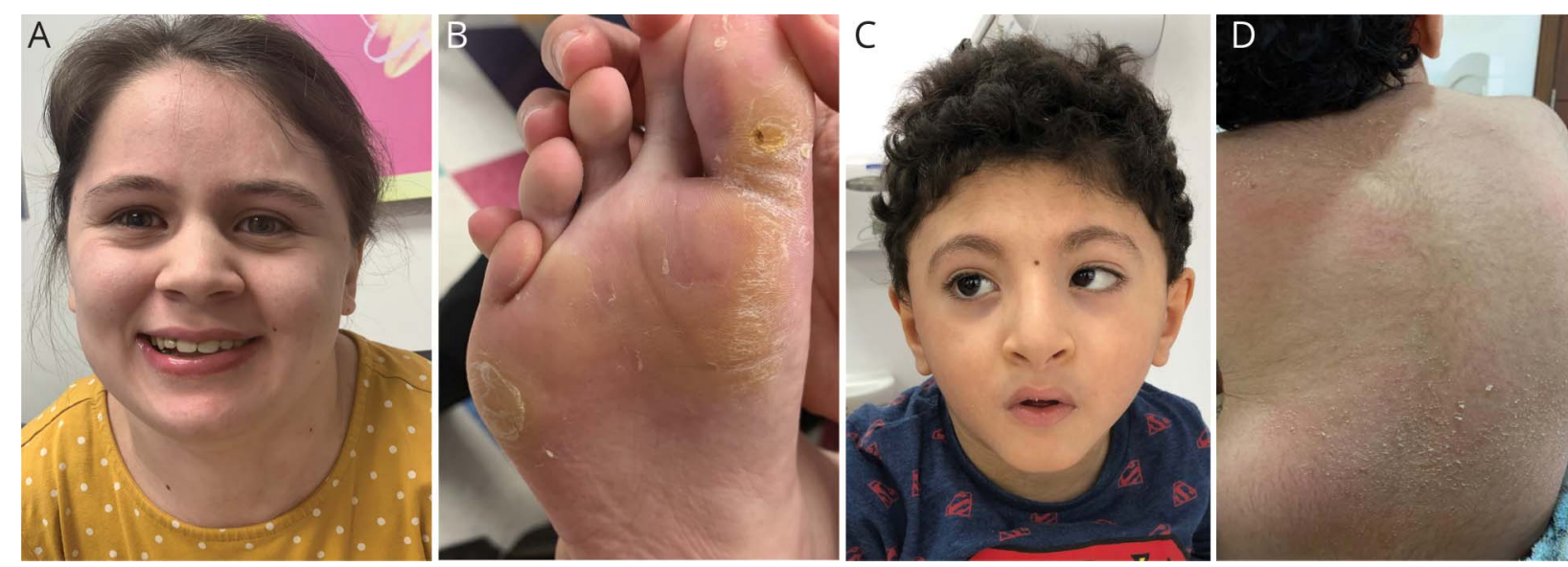

There was no recognizable gestalt of features among the patients described in this study. Patient 1 (age 18) displays (A) mild hypotelorism and (B) keratoderma of the soles of the feet. Patient 5 (age 6) displays (C) short forehead with bitemporal narrowing, low-set ears, microphthalmia, high-arched palate. Epicanthal folds, strabismus, anteverted nares, a short philtrum with bowed upper lip, micrognathia, a high-arched palate, and (D) generalized ichthyosis, here shown on the back. CEDNIK = cerebral dysgenesis, neuropathy, ichthyosis, and keratoderma.

On physical examination at the age of 7 , her height and weight were $<1$ st and 11th percentile, respectively. She is microcephalic with bitemporal narrowing and has thick eyebrows, epicanthal folds, and flaring nares with a bulbous nasal tip. Her skin examination showed diffuse ichthyosis that peels extensively every few days and palmoplantar keratoderma (figure e-1, links.lww.com/ $\mathrm{NXG}$ /A366). She is nonverbal and exhibits repetitive behaviors, purposeless movements, and roving eye movements. Ophthalmologic examination showed nystagmus and foveal hypoplasia. Neurologic examination showed increased muscle tone in the lower extremities and bilateral sensorineural deafness.

\section{Patient 4}

Patient 4 is a 4-year-old girl of Tibetan \& Indian descent. Her parents have no known consanguinity. She was the second of 3 pregnancies and delivered at full term; her siblings are healthy (figure 1B).

At 18 months, patient 4 required a G-tube for feeding difficulties and poor weight gain. She has global DD complicated by cortical visual impairment and profound sensorineural deafness. At the age of 4 , she can form a pincer grasp but is unable to walk because of profound hypotonia. She does not speak. She had multiple admissions for aspiration pneumonia. She takes omeprazole for gastroesophageal reflux, domperidone for gastrointestinal dysmotility, and salbutamol and fluticasone propionate for asthma.

On physical examination at the age of 3 , height, weight, and OFC were 3-10th, 10th, and 50th percentile, respectively. Dysmorphic features include plagiocephaly, right-hand single palmar crease, and thinning hair at the temporal regions. Skin examination showed ichthyosis without keratoderma (figure e-1, links.lww.com/NXG/A366). Ophthalmologic examination showed hyperopia, nystagmus, and strabismus.

\section{Patient 5}

Patient 5 is a 7-year-old boy of Arabian descent whose parents are third cousins (figure 1B). He was born at term after an uncomplicated pregnancy and noted to have craniofacial dysmorphism, hypotonia, and nystagmus at birth.

During infancy, patient 5 had feeding difficulties, gastroesophageal reflux, failure to thrive, and recurrent respiratory tract infections leading to multiple hospitalizations. He also had a $1 \mathrm{~mm}$ patent foramen ovale that resolved. He developed seizures at 4 months with multifocal epileptiform discharges on EEG, for which he took phenobarbitone until seizures resolved at the age of 2 . At 2.5 years old, he was $<2$ nd percentile for OFC and weight (from 12th and 34th at birth). He sat with support at the age of 3 and stood with support at the age of 3.5 , but at the age of 7 , he no longer stands independently. He holds a spoon but cannot feed himself. His first word was at 2.5 years old, and his vocabulary is restricted to 2 words.

On physical examination at the age of 6.5 , height, weight, and $O F C$ were $<2$ nd, 5 th, and 2 nd percentile, respectively. Patient 5 has microcephaly with a short forehead and bitemporal narrowing, low-set ears, microphthalmia, epicanthal folds, anteverted nares, a short philtrum with bowed upper lip, micrognathia, and a high-arched palate (figure 2C). Examination also showed hypotonia, scoliosis, and generalized ichthyosis without palmoplantar keratoderma (figure 2D). Ophthalmologic examination showed horizontal nystagmus, convergent strabismus, and myopia.

\section{Patient 6}

Patient 6 is a 2-year-old Brazilian boy whose parents are second cousins (figure 1B). He was born at term after an uncomplicated 
Figure 3 Brain MRI of Patient 1 Shows Corpus Callosum Dysgenesis and Loss of Supratentorial Myelin
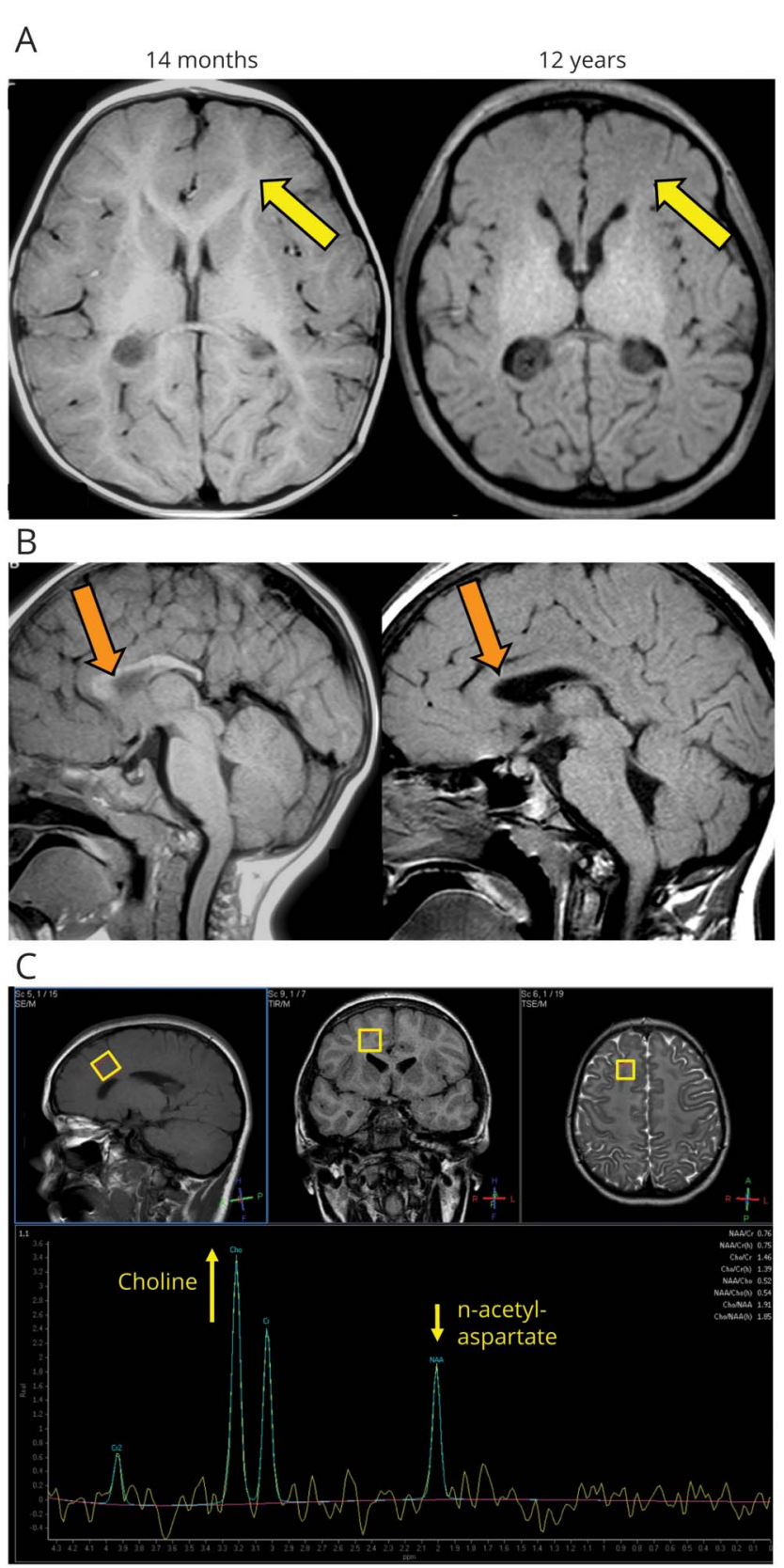

(A) T1-weighted MRI showing normal myelination at 14 months but loss of normal T1 hyperintense white matter signal at 12 years consistent with severe hypomyelination (yellow arrows). (B) T1-weighted MRI showing dysgenesis of the corpus callosum with a deficient splenium. Although there is normal myelin in the genu of the corpus callosum at 14 months, it is lost at 12 years (orange arrows). In addition, there is platybasia with resultant kinking of the medulla oblongata. (C) Single voxel proton MR spectroscopy with TE $144 \mathrm{~ms}$ at 12 years of age. Top row: T1W, T2 FLAIR, and T2W images show abnormal white matter. Bottom row: spectrum shows elevated choline relative to $n$-acetylaspartate (NAA) in the right frontal lobe white matter, consistent with the loss of sphingolipid in the myelin and suggestive of myelin breakdown. A normal spectrum should show reversed levels of NAA and choline. ${ }^{17}$.

pregnancy and was noted to have shortened Achilles tendons. He required a 1-month NICU stay for fever, hypoglycemia, and thrombophilia, possibly related to SERPIND1/heparin cofactor II deficiency (see Molecular Results). ${ }^{16}$
He eats well but has difficulty gaining weight. He has global $\mathrm{DD}$; at the age of 2, he sits with support but cannot walk and babbles without producing words. He has significant hearing loss and right optic nerve hypoplasia. He takes laxatives for constipation and melatonin for difficulty sleeping.

At the age of 2, height, weight, and OFC were $<2 \mathrm{nd}$, 10th, and $\sim 70$ th percentile, respectively. He has mildly dysmorphic features with synophrys, bushy eyebrows, epicanthal folds, and a broad, depressed nasal bridge. Skin findings include ichthyosis and plantar keratoderma (figure e-1, links.lww. com/NXG/A366). He has truncal hypotonia, poor limb movement, and tight Achilles tendons.

\section{Radiologic Findings}

Typical radiographic findings of CEDNIK syndrome are dysgenesis of the corpus callosum and PMG. Corpus callosum dysgenesis was seen in the brain MRIs of all patients except patient 3 (figures 3, e-3, e-4, e-5, links.lww.com/NXG/A366). Patient 3's MRI was read as bilateral PMG, stable from 18 months to 8 years of age (data not shown), and patient 4 has possible PMG at the Sylvian fissures (figure e-4); patient 5's MRIs at 4 days and 10 months of age were initially reported as lissencephaly with PMG and mild cerebellar hypoplasia, although this finding was not clear on reread at another institution (figure 4). However, imaging of patients 1, 2, and 6 did not show evidence of PMG.

The most striking and under-recognized finding in this cohort of patients was white matter T1 hypointensity/T2 hyperintensity consistent with decreased sphingolipid in the myelin sheath, characteristic of white matter disease. Patient 1 had serial MRIs showing fairly normal supratentorial white matter at 14 months of age but a striking lack of supratentorial myelin signal by age 12 years (figure 3, e-2, links.lww.com/NXG/ A366). MR spectroscopy showed increased choline relative to n-acetylaspartate, consistent with metabolic breakdown of the myelin sheath. ${ }^{17}$ MRIs from patient 2 (age 3, figure e-3), patient 4 (age 2, figure e-4), and patient 6 ( 7 months, data not shown) also suggest decreased supratentorial myelin content. Although less severe, patient 5 had subtle hypomyelination in the occipital region at 10 months (figure 4). Loss of white matter, especially in the occipital areas, may have led to enlargement of the occipital horns of the lateral ventricles in patients 2 (figure e-3), 5 (figure e-5), and 6 (data not shown).

We also describe several structural abnormalities that were not previously associated with CEDNIK syndrome. Four patients had an abnormal craniocervical junction with narrowing of the foramen magnum, represented by imaging from patient 1 showing platybasia with kinking of the medulla oblongata (figure 3), but also present in patients 2, 4, and 5 . Representative imaging from patient 5 (figure 4) shows abnormalities in the Sylvian fissure that were also present in patients 2 and 4, and T2 hyperintensity of the globus pallidi shared with patient 4 . T2 hyperintensity of the basal ganglia is often linked to hypoxic, toxic, and/or metabolic insult, but its underlying cause in CEDNIK syndrome is unclear. 
Figure 4 Brain MRI of Patient 5 Shows Small Frontal Lobes, Abnormal Sylvian Fissures, and T2 Hyperintensity of the Globus Pallidus
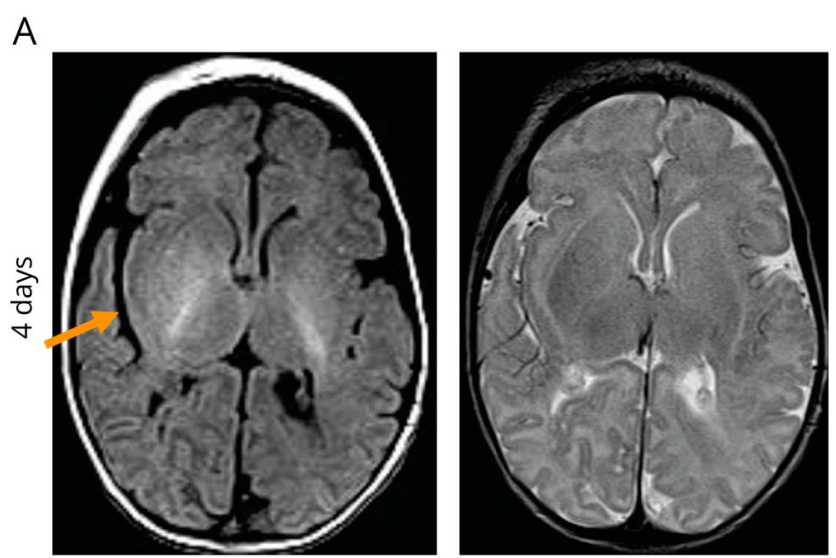

B T1W $\mathrm{T} 2 \mathrm{~W}$

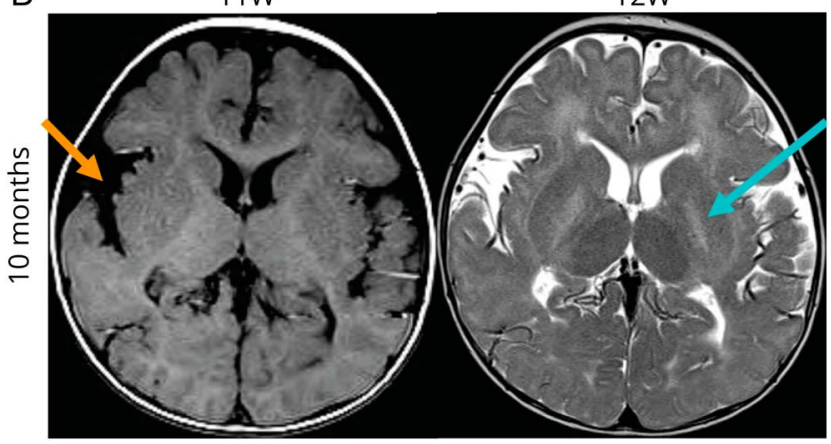

Axial T1W and T2W images at (A) 4 days of life and (B) at 10 month old Structural findings include small frontal lobes and abnormal Sylvian fissures (orange arrows). Myelination in the newborn period is normal above the tentorium because only the posterior limb of the internal capsule should be myelinated. ${ }^{22}$ (B) At 10 months, there is subtle hypomyelination in the occipital regions, but some normal myelin is seen in the genu of the corpus callosum. There is high T2W signal in the globus pallidus bilaterally (cyan arrow).

\section{Discussion}

We describe 6 additional patients with CEDNIK syndrome and review previously reported phenotypes and genotypes. To date, 10 distinct variants in SNAP29 are associated with disease in humans (table 1, figure 1A), including 4 heterozygous variants found in the context of 22q11.2 deletion syndrome that were excluded from our phenotypic analysis. ${ }^{18}$ Patient 6 was included because his $370 \mathrm{~kb}$ deletion affected only 3 OMIM genes other than SNAP29, for which no variants were detected; however, we cannot completely exclude contribution of these genes to his neurologic phenotype.

In the 19 patients with homozygous or compound heterozygous SNAP29 mutations reported earlier, ${ }^{1-9}$ no clear genotype-phenotype correlation emerged (table 2). Compared with previous reports, patients in this report had a higher occurrence of seizures $(3 / 6$ vs $7 / 19)(p=0.5741)$, strabismus $(4 / 6$ vs $2 / 19)(p=0.0060)$, early puberty in pubescent patients $(2 / 3$ vs $1 / 2)(p=0.7390)$, hypomyelination
$(4 / 6$ vs $3 / 16)(p=0.0291)$, and constipation (3/6 vs $0 / 19)(p$ $=0.0013$ ) than previously reported (table 2 ). Although increased reporting of findings such as constipation and strabismus may be associated with changes in diagnosis since earlier publications, other associations expand our understanding of the disease phenotypes caused by SNAP29 variants.

These patients have widened the genotypic and phenotypic spectrum of CEDNIK syndrome in several ways. First, 2 patients had early puberty, which was only reported in a single previous case of CEDNIK syndrome. ${ }^{4}$ SNAP29 may play an undiscovered role in sex hormone production because the highest expression of SNAP29 is in the testes, and the expression in ovary is higher than all brain tissues analyzed. ${ }^{19}$ Given that many patients were prepubescent at time of publication, further investigation into the role of SNAP29 in endocrine regulation is required.

Second, we report a 19-year-old patient who may be the longest-surviving individual diagnosed with CEDNIK syndrome. Patients 1 and 2 are respectively the oldest patient and most neurologically functional patient described so far. We hypothesize that these unique features are because of lowlevel production of the c.2T>C; p.Met1? variant of SNAP29, as transcripts with disrupted initiation codons can be translated using alternate start sites or alternate initiation codon sequences. ${ }^{20}$ Evidence from one previously reported patient showed mRNA from the c. $2 \mathrm{~T}>\mathrm{C}$ allele was detectable in the blood, but Western blotting of fibroblasts did not detect SNAP29 protein expression. $^{7}$ It is unknown whether low levels of SNAP29 not detectable by Western blot could be mitigating the phenotypes of patients 1 and 2 .

Third, we present a novel nonsense mutation in the final exon, c.622G $>$ T (p.Glu208*), suggesting production of a truncated protein. All previously reported frameshift and nonsense variants are predicted to cause loss of function through nonsensemediated mRNA decay (NMD). This truncated protein is likely not functional, given the patient's significant disease burden, with corpus callosum and white matter loss, profound hypotonia, blindness, deafness, and dysmorphic features. It is possible that this variant has unique function, for example, interfering with soluble $\mathrm{N}$-ethylmaleimide-sensitive factor attachment protein receptor (SNAP)/SNAP receptor (SNARE) complex formation because of interruption of the C-SNARE domain.

Fourth, brain imaging of these patients identified several abnormalities not previously associated with CEDNIK syndrome. Four of 6 patients had white matter changes consistent with significantly decreased myelin content. Patient 1 's loss of myelin between age 14 months and 12 years of age seems radiographically similar to Pelizaeus-Merzbacher disease and could represent progressive hypomyelination. Although the c.2T $>C$ variant (carried by patients 1 and 2 ) was described in a patient with hypomyelinating leukodystrophy diagnosed with PMLD, ${ }^{7}$ the phenotype does not seem to be exclusive to this variant because other patients (patients 4,6 , 
Table 2 Clinical Phenotypes Associated With CEDNIK Syndrome

\begin{tabular}{|c|c|c|c|c|c|c|c|c|c|c|c|c|c|c|c|}
\hline Reference & (1) & (2) & (3) & (4) & (5) & (6) & (7) & (8),(9) & Pt 1 & Pt 2 & $\begin{array}{l}\mathrm{Pt} \\
3\end{array}$ & $\begin{array}{l}\mathrm{Pt} \\
4\end{array}$ & Pt 5 & Pt 6 & Total \\
\hline Sex & $\begin{array}{l}3 \mathrm{~F} \\
4 \mathrm{M}\end{array}$ & $1 \mathrm{~F}, 1 \mathrm{M}$ & $2 \mathrm{~F}$ & $1 \mathrm{M}$ & $1 \mathrm{~F}$ & $1 \mathrm{M}$ & $1 \mathrm{M}$ & $1 \mathrm{~F}, 3 \mathrm{M}$ & $\mathrm{F}$ & M & $\mathrm{F}$ & $\mathrm{F}$ & M & M & $11 \mathrm{~F}, 14 \mathrm{M}$ \\
\hline Age & $5-13$ & $\begin{array}{l}11 \mathrm{mo}, \\
4 \mathrm{y}\end{array}$ & $\begin{array}{l}4 \\
y^{c}\end{array}$ & $\begin{array}{l}10 \\
y\end{array}$ & $\begin{array}{l}20 \\
\text { mo }\end{array}$ & $\begin{array}{l}26 \\
\text { mo }\end{array}$ & $\begin{array}{l}12 \\
y\end{array}$ & $\begin{array}{l}2.5-12 \\
y\end{array}$ & $19 y$ & $13 y$ & $9 y$ & $4 y$ & $7 y$ & $2 y$ & $\begin{array}{l}11 \mathrm{mo}- \\
19 \mathrm{y}\end{array}$ \\
\hline Consanguinity & $7 / 7$ & $2 / 2$ & $\begin{array}{l}2 / \\
2\end{array}$ & $\begin{array}{l}1 / \\
1\end{array}$ & $1 / 1$ & $0 / 1$ & $\begin{array}{l}0 / \\
1\end{array}$ & $4 / 4$ & Yes & Yes & Yes & No & Yes & Yes & $\begin{array}{l}22 / 25 \\
(88 \%)\end{array}$ \\
\hline \multicolumn{16}{|l|}{ Development } \\
\hline Feeding difficulty & $7 / 7$ & $2 / 2$ & $\begin{array}{l}2 / \\
2\end{array}$ & $\begin{array}{l}1 / \\
1\end{array}$ & $1 / 1$ & $1 / 1$ & $\begin{array}{l}0 / \\
1\end{array}$ & N/A & No & No & Yes & Yes & Yes & No & $\begin{array}{l}17 / 21 \\
(81 \%)\end{array}$ \\
\hline GDD & $7 / 7$ & $2 / 2$ & $\begin{array}{l}2 / \\
2\end{array}$ & $\begin{array}{l}1 / \\
1\end{array}$ & $1 / 1$ & $1 / 1$ & $\begin{array}{l}1 / \\
1^{\mathrm{a}}\end{array}$ & $4 / 4$ & Yes & Yes $^{a}$ & Yes & Yes & Yes & Yes & $\begin{array}{l}25 / 25 \\
(100 \%)\end{array}$ \\
\hline Early puberty & N/A & N/A & $\begin{array}{l}\mathrm{N} / \\
\mathrm{A}\end{array}$ & $\begin{array}{l}1 / \\
1\end{array}$ & N/A & N/A & $\begin{array}{l}0 / \\
1\end{array}$ & $\mathrm{~N} / \mathrm{A}$ & Yes & No & Yes & $\begin{array}{l}\mathrm{N} / \\
\mathrm{A}\end{array}$ & N/A & $\mathrm{N} / \mathrm{A}$ & $3 / 5(60 \%)$ \\
\hline $\begin{array}{c}\text { Respiratory } \\
\text { infections }\end{array}$ & $3 / 7^{d}$ & $1 / 2$ & $\begin{array}{l}1 / \\
2\end{array}$ & $\begin{array}{l}1 / \\
1\end{array}$ & $1 / 1$ & $0 / 1$ & $\begin{array}{l}0 / \\
1\end{array}$ & $1 / 4^{d}$ & No & No & Yes & Yes & Yes & Yes & $\begin{array}{l}12 / 25 \\
(48 \%)\end{array}$ \\
\hline \multicolumn{16}{|c|}{ Neurologic and Brain MRI Findings } \\
\hline $\begin{array}{l}\text { Corpus callosum } \\
\text { abnormality }\end{array}$ & $4 / 4$ & $2 / 2$ & $\begin{array}{l}2 / \\
2\end{array}$ & $\begin{array}{l}1 / \\
1\end{array}$ & $1 / 1$ & $1 / 1$ & $\begin{array}{l}1 / \\
1\end{array}$ & $4 / 4$ & Yes & Yes & No & Yes & Yes & Yes & $\begin{array}{l}21 / 22 \\
(95 \%)\end{array}$ \\
\hline Polymicrogyria & $4 / 4$ & $1 / 2$ & $\begin{array}{l}0 / \\
2\end{array}$ & $\begin{array}{l}1 / \\
1\end{array}$ & $1 / 1$ & $1 / 1$ & $\begin{array}{l}0 / \\
1\end{array}$ & $4 / 4$ & No & No & Yes & No & $\mathrm{Yes}^{\mathrm{c}}$ & No & $\begin{array}{l}14 / 22 \\
(64 \%)\end{array}$ \\
\hline Hypomyelination & $0 / 4$ & $0 / 2$ & $\begin{array}{l}0 / \\
2\end{array}$ & $\begin{array}{l}1 / \\
1\end{array}$ & $1 / 1$ & $0 / 1$ & $\begin{array}{l}1 / \\
1\end{array}$ & $0 / 4$ & Yes & Yes & No & Yes & No & Yes & $\begin{array}{l}7 / 22 \\
(32 \%)\end{array}$ \\
\hline Seizures & $0 / 7$ & $1 / 2^{c}$ & $\begin{array}{l}0 / \\
2\end{array}$ & $\begin{array}{l}0 / \\
1\end{array}$ & $0 / 1$ & $1 / 1$ & $\begin{array}{l}0 / \\
1\end{array}$ & $4 / 4$ & Yes & Yes & No & No & Yes & No & $\begin{array}{l}9 / 25 \\
(36 \%)\end{array}$ \\
\hline Microcephaly & $7 / 7$ & $2 / 2$ & $\begin{array}{l}0 / \\
2\end{array}$ & $\begin{array}{l}0 / \\
1\end{array}$ & $1 / 1$ & $0 / 1$ & $\begin{array}{l}0 / \\
1\end{array}$ & $1 / 4$ & No & No & Yes & No & Yes & No & $\begin{array}{l}13 / 25 \\
(52 \%)\end{array}$ \\
\hline \multicolumn{16}{|l|}{ Musculoskeletal } \\
\hline Truncal hypotonia & $7 / 7$ & $2 / 2$ & $\begin{array}{l}21 \\
2\end{array}$ & $\begin{array}{l}1 / \\
1\end{array}$ & $1 / 1$ & $1 / 1$ & $\begin{array}{l}1 / \\
1\end{array}$ & $4 / 4$ & Yes & Yes & Yes & Yes & Yes & Yes & $\begin{array}{l}25 / 25 \\
(100 \%)\end{array}$ \\
\hline Limb spasticity & $0 / 7$ & $2 / 2$ & $\begin{array}{l}0 / \\
2\end{array}$ & $\begin{array}{l}1 / \\
1\end{array}$ & $1 / 1$ & $0 / 1$ & $\begin{array}{l}1 / \\
1^{a}\end{array}$ & $0 / 4$ & Yes & Yes & Yes & No & No & Yes & $\begin{array}{l}7 / 13 \\
(54 \%)\end{array}$ \\
\hline Scoliosis & N/A & $0 / 1$ & $\begin{array}{l}0 / \\
2\end{array}$ & $\begin{array}{l}1 / \\
1\end{array}$ & $1 / 1^{a}$ & $0 / 1$ & $\begin{array}{l}0 / \\
1\end{array}$ & N/A & Yes & No & No & No & Yes & $0 / 1$ & $\begin{array}{l}4 / 13 \\
(31 \%)\end{array}$ \\
\hline
\end{tabular}

Eye and ear

\begin{tabular}{|c|c|c|c|c|c|c|c|c|c|c|c|c|c|c|c|}
\hline $\begin{array}{l}\text { Optic atrophy/ } \\
\text { hypoplasia }\end{array}$ & $7 / 7$ & $\mathrm{~N} / \mathrm{A}$ & $\begin{array}{l}21 \\
2\end{array}$ & $\begin{array}{l}1 / \\
1\end{array}$ & $0 / 1$ & $\mathrm{~N} / \mathrm{A}$ & $\begin{array}{l}1 / \\
1^{\mathrm{a}}\end{array}$ & $4 / 4$ & No & No & No & No & No & Yes & $\begin{array}{l}16 / 22 \\
(73 \%)\end{array}$ \\
\hline $\begin{array}{l}\text { Roving eye } \\
\text { movements }\end{array}$ & $7 / 7$ & $1 / 2$ & $\begin{array}{l}0 / \\
2\end{array}$ & $\begin{array}{l}0 / \\
1\end{array}$ & $1 / 1$ & $0 / 1$ & $\begin{array}{l}0 / \\
1\end{array}$ & N/A & No & No & Yes & No & No & No & $\begin{array}{l}10 / 21 \\
(48 \%)\end{array}$ \\
\hline Nystagmus & $\mathrm{N} / \mathrm{A}$ & $0 / 2$ & $\begin{array}{l}0 / \\
2\end{array}$ & $\begin{array}{l}0 / \\
1\end{array}$ & $0 / 1$ & $0 / 1$ & $\begin{array}{l}1 / \\
1\end{array}$ & $\mathrm{~N} / \mathrm{A}$ & No & No & No & Yes & Yes & No & $\begin{array}{l}3 / 14 \\
(21 \%)\end{array}$ \\
\hline Strabismus & N/A & $\mathrm{N} / \mathrm{A}$ & $\begin{array}{l}0 / \\
2\end{array}$ & $\begin{array}{l}1 / \\
1\end{array}$ & $0 / 1$ & $0 / 1$ & $\begin{array}{l}1 / \\
1^{\mathrm{b}}\end{array}$ & $\mathrm{N} / \mathrm{A}$ & Yes & Yes & Yes & No & Yes & No & $\begin{array}{l}6 / 12 \\
(50 \%)\end{array}$ \\
\hline Hearing loss & $3 / 7^{a}$ & $2 / 2$ & $\begin{array}{l}0 / \\
2\end{array}$ & $\begin{array}{l}0 / \\
1\end{array}$ & $1 / 1$ & $0 / 1$ & $\begin{array}{l}0 / \\
1\end{array}$ & $\mathrm{~N} / \mathrm{A}$ & No & No & Yes & Yes & No & Yes & $\begin{array}{l}9 / 21 \\
(43 \%)\end{array}$ \\
\hline \multicolumn{16}{|l|}{ Dermatologic } \\
\hline Ichthyosis & $7 / 7$ & $2 / 2^{a}$ & $\begin{array}{l}2 / \\
2^{\mathrm{e}}\end{array}$ & $\begin{array}{l}1 / \\
1\end{array}$ & $1 / 1$ & $1 / 1$ & $\begin{array}{l}0 / \\
1\end{array}$ & $0 / 4$ & $Y_{e s}^{a}$ & Yes & Yes & Yes & Yes & Yes & $\begin{array}{l}20 / 25 \\
(80 \%)\end{array}$ \\
\hline Keratoderma & $7 / 7$ & $2 / 2$ & $\begin{array}{l}2 / \\
2\end{array}$ & $\begin{array}{l}1 / \\
1\end{array}$ & $1 / 1^{a}$ & $0 / 1$ & $\begin{array}{l}0 / \\
1\end{array}$ & $0 / 4$ & Yes & Yes & Yes & No & No & Yes & $\begin{array}{l}17 / 25 \\
(68 \%)\end{array}$ \\
\hline
\end{tabular}


Table 2 Clinical Phenotypes Associated With CEDNIK Syndrome (continued)

\begin{tabular}{|c|c|c|c|c|c|c|c|c|c|c|c|c|c|c|c|}
\hline Reference & (1) & (2) & (3) & (4) & (5) & (6) & (7) & (8),(9) & Pt 1 & Pt 2 & $\begin{array}{l}\mathrm{Pt} \\
3\end{array}$ & $\begin{array}{l}\mathrm{Pt} \\
4\end{array}$ & Pt 5 & Pt 6 & Total \\
\hline \multicolumn{16}{|l|}{ Dysmorphic features } \\
\hline Dysmorphic face & $7 / 7$ & $2 / 2$ & $\begin{array}{l}2 / \\
2\end{array}$ & $\begin{array}{l}1 / \\
1\end{array}$ & $1 / 1$ & $1 / 1$ & $\begin{array}{l}0 / \\
1\end{array}$ & $0 / 4$ & No & No & Yes & Yes & Yes & $Y^{a}{ }^{a}$ & $\begin{array}{l}18 / 25 \\
(72 \%)\end{array}$ \\
\hline Face shape & \multicolumn{15}{|c|}{ Elongated $(8)^{1,2}$, round $(2)^{\mathrm{Pt} 1, \mathrm{Pt} 2}$, short forehead w/bitemporal narrowing $(1)^{\mathrm{Pt} 5}$, brachycephaly/triangular $(2)^{3}$, plagiocephaly $(1)^{\mathrm{Pt} 3}$} \\
\hline Eyes & \multicolumn{15}{|c|}{$\begin{array}{l}\text { Hypertelorism }(10)^{1,5, \mathrm{Pt} 1, \mathrm{Pt} 2} \text {, deep-set }(3)^{4, \mathrm{Pt} 1, \mathrm{Pt} 2} \text {, downslanting palpebral fissures }(9)^{1,3}, \text { epicanthal folds }(4)^{6, \mathrm{Pt} 3, \mathrm{Pt} 5, \mathrm{Pt} 6} \text {, } \\
\text { microphthalmia }(1)^{\mathrm{Pt} 5}\end{array}$} \\
\hline Ears & \multicolumn{15}{|c|}{ Large ears $(1)^{4}$, low-set ears $(2)^{5, \mathrm{Pt} 5}$, small ears with folded helix $(2)^{3}$} \\
\hline Nose & \multicolumn{15}{|c|}{ Flat, broad root $(11)^{1,3,5, \mathrm{Pt} 6}$, large/long $(2)^{2,4}$, pointed tip $(2)^{2}$, bulbous tip $(1)^{\mathrm{Pt} 3}$, anteverted nares $(1)^{\mathrm{Pt} 5}$, midface hypoplasia $(1)^{6}$} \\
\hline Mouth & \multicolumn{15}{|c|}{ Small chin $(1)^{2}$, short philtrum $(1)^{\mathrm{Pt} 5}$, retrognathia $(1)^{6}$, micrognathia + high-arched palate $(4)^{2,3, \mathrm{Pt} 5}$, bifid uvula $(1)^{4}$} \\
\hline Ectodermal & \multicolumn{15}{|c|}{$\begin{array}{l}\text { Sparse, brittle hair }(2)^{2} \text {, thin hair at temples }(1)^{\mathrm{Pt} 3} \text {, hirsuitism/low hairline }(1)^{4} \text {, synophrys }(3)^{4,5, \mathrm{Pt} 6} \text {, hypohidrosis }(1)^{4} \text {, enamel } \\
\text { hypoplasia }(1)^{5}\end{array}$} \\
\hline Skeletal & \multicolumn{15}{|c|}{ Talipes equinovarus $(1)^{2}$, knee contractures $(1)^{2}$, coxa valga $(1)^{4}$, camptodactyly $(2)^{3}$, radial deviation of wrists $(2)^{3}$, clinodactyly $(2)^{4,5}$} \\
\hline Other & \multicolumn{15}{|c|}{ Small fontanelles $(2)^{2}$, scarring alopecia $(1)^{2}$, flat maxilla $(1)^{3}$, colpocephaly $(3)^{8}$, inverted nipples $(1)^{2}$, single palmar crease $(1)^{\mathrm{Pt} 3}$} \\
\hline \multicolumn{16}{|c|}{$\begin{array}{l}\text { Denominator can be different from } 25 \text { based on a } \\
\text { "N/A" - clinical phenotype not assessed. Otherwise } \\
\text { viral illness and pneumonia. Early puberty was no } \\
\text { hyperintensity, and white matter loss. Spasticity in } \\
\text { were hyporeflexive or flaccid. Spasticity and scolic } \\
\text { Dysmorphic features listed with (No. of patients a } \\
\text { a Mild or moderate phenotype. } \\
\text { b Intermittent exotropia. } \\
\text { " Uncertain. } \\
\text { "Deaths from pneumonia/respiratory infection. } \\
\text { e Collodion phenotype. }\end{array}$} \\
\hline
\end{tabular}

and 2 previously described cases of CEDNIK syndrome ${ }^{4,5}$ ) had imaging evidence consistent with hypomyelination/white matter loss. Thus, there is growing evidence that hypomyelination may be a feature of CEDNIK syndrome, supported by data showing high SNAP29 expression in myelinating glial cells. ${ }^{21}$ Serial imaging in future patients could help determine which SNAP29 variants are associated with this pattern of white matter disease. In addition, abnormal craniocervical junction (C1-C2) anatomy in our patients led to narrowing of the foramen magnum and kinking of the medulla. Although patients with both SNAP29 and TUBA8 variants had loss of the pontomedullary junction, ${ }^{8,9}$ our findings have not been previously described in patients with CEDNIK syndrome and whether they contribute to the disease phenotype is uncertain.

Finally, there are a growing number of patients in the literature with SNAP29 pathogenic variants were not diagnosed with CEDNIK syndrome because of the lack of ichthyosis or keratoderma. ${ }^{7-9}$ In fact, keratoderma and ichthyosis were described in only $80 \%$ and $68 \%$ of cases, respectively (table 2 ). One such patient who was compound heterozygous for $\mathrm{c} .2 \mathrm{~T}>\mathrm{C}$ and c.354dupG variants in SNAP29 was diagnosed with PMLD. ${ }^{7}$ Although previous homozygous cases of c. $2 \mathrm{~T}>\mathrm{C}$ and c.354dupG had skin findings typical of CEDNIK syndrome, this compound heterozygous patient did not, suggesting reduced penetrance of dermatologic disease with SNAP29 loss-of-function. This is supported by Snap29-deficient mouse models, suggesting that genetic or nongenetic modifiers affect skin findings. ${ }^{13}$ The lack of dermatologic findings in these patients can mislead clinicians who may fail to test for SNAP29 variants. Furthermore, only a few of the recently reported patients had PMG or neuropathy typical of CEDNIK syndrome, although neuropathy has not been systematically evaluated. We believe that the skin findings, cerebral dysgenesis, and neuropathy that were initially thought to be cardinal features of this condition are not mandatory to establish a disease diagnosis.

Given incomplete penetrance for ichthyosis, keratoderma, neuropathy, and cerebral dysgenesis phenotypes in patients with SNAP29 pathogenic variants (table 2), we propose the nomenclature SNAP29-related disorder instead of CEDNIK syndrome for all patients with deleterious SNAP29 variants regardless of their phenotypic features.

We report 6 new patients with predicted loss-of-function variants in SNAP29. All patients exhibit DD, ichthyosis and/or palmoplantar keratoderma, and hypotonia. We highlight previously under-recognized features such as supratentorial hypomyelination, seizures, and early puberty. We also find growing evidence for reduced penetrance for the skin phenotype, cerebral dysgenesis, and neuropathy. Significant phenotypic variability in patients with SNAP29 variants suggests that CEDNIK syndrome should be defined genetically rather than as a specific constellation of neurologic, brain imaging, and skin findings. 


\section{Acknowledgment}

The authors thank the families of the patients described for participating in this study. Thank you for being engaged, dedicated, and curious.

\section{Study Funding}

A.Y.M. was supported by NIAID F30 AI129110.

\section{Disclosure}

The authors report no disclosures. Go to Neurology.org/NG for full disclosures.

\section{Publication History}

Received by Neurology: Genetics May 22, 2020. Accepted in final form November 18, 2020.

\section{Appendix Authors}

\begin{tabular}{|c|c|c|}
\hline Name & Location & Contribution \\
\hline $\begin{array}{l}\text { Annelise Y. Mah- } \\
\text { Som, MD, PhD }\end{array}$ & $\begin{array}{l}\text { Washington } \\
\text { University in St. Louis, } \\
\text { St. Louis, MO }\end{array}$ & $\begin{array}{l}\text { Reviewed and } \\
\text { interpreted patient data } \\
\text { and drafted the } \\
\text { manuscript }\end{array}$ \\
\hline $\begin{array}{l}\text { Cristina Skrypnyk, } \\
\text { MD, PhD }\end{array}$ & $\begin{array}{l}\text { Arabian Gulf } \\
\text { University, Bahrain }\end{array}$ & $\begin{array}{l}\text { Collected patient data } \\
\text { and revised the } \\
\text { manuscript for } \\
\text { intellectual content }\end{array}$ \\
\hline $\begin{array}{l}\text { Andrea Guerin, } \\
\text { MD }\end{array}$ & $\begin{array}{l}\text { Queen's University } \\
\text { Kingston, Canada }\end{array}$ & $\begin{array}{l}\text { Collected patient data } \\
\text { and revised the } \\
\text { manuscript for } \\
\text { intellectual content }\end{array}$ \\
\hline $\begin{array}{l}\text { Raafat Hammad } \\
\text { Seroor Jadah, } \\
\text { MBBCh, AB Ped, SB } \\
\text { Ped }\end{array}$ & $\begin{array}{l}\text { Bahrain Defense } \\
\text { Forces Royal Medical } \\
\text { Services Hospital, } \\
\text { Bahrain }\end{array}$ & $\begin{array}{l}\text { Collected patient data } \\
\text { and revised the } \\
\text { manuscript for } \\
\text { intellectual content }\end{array}$ \\
\hline $\begin{array}{l}\text { Vinayak Nivrutti } \\
\text { Vardhan, MBBS, } \\
\text { DCH }\end{array}$ & $\begin{array}{l}\text { Bahrain Defense } \\
\text { Forces Royal Medical } \\
\text { Services Hospital, } \\
\text { Bahrain }\end{array}$ & $\begin{array}{l}\text { Collected patient data } \\
\text { and revised the } \\
\text { manuscript for } \\
\text { intellectual content }\end{array}$ \\
\hline $\begin{array}{l}\text { Robert C. } \\
\text { McKinstry, MD } \\
\text { PhD }\end{array}$ & $\begin{array}{l}\text { Washington } \\
\text { University in St. Louis, } \\
\text { St. Louis, MO }\end{array}$ & $\begin{array}{l}\text { Reviewed patient } \\
\text { imaging and revised the } \\
\text { manuscript for } \\
\text { intellectual content }\end{array}$ \\
\hline $\begin{array}{l}\text { Marwan S. } \\
\text { Shinawi, MD }\end{array}$ & $\begin{array}{l}\text { Washington } \\
\text { University in St. Louis, } \\
\text { St. Louis, MO }\end{array}$ & $\begin{array}{l}\text { Conceptualized and } \\
\text { coordinated the study } \\
\text { and revised the } \\
\text { manuscript for } \\
\text { intellectual content }\end{array}$ \\
\hline
\end{tabular}

\section{References}

1. Sprecher E, Ishida-Yamamoto A, Mizrahi-Koren M, et al. A mutation in SNAP29, coding for a SNARE protein involved in intracellular trafficking, causes a nove neurocutaneous syndrome characterized by cerebral dysgenesis, neuropathy, ichthyosis, and palmoplantar keratoderma. Am J Hum Genet 2005;77:242-251.

2. Fuchs-Telem D, Stewart H, Rapaport D, et al. CEDNIK syndrome results from lossof-function mutations in SNAP29. Br J Dermatol 2011;164:610-616.

3. Ben-Salem S, Nara S, Al-Shamsi AM, Valle D, Ali BR, Al-Gazali L. New Arab family with cerebral dysgenesis, neuropathy, ichthyosis, and keratoderma syndrome suggests a possible founder effect for the c.223delG mutation. J Dermatol 2015;42:821-822.

4. Hsu T, Coughlin CC, Monaghan KG, et al. CEDNIK: phenotypic and molecular characterization of an additional patient and review of the literature. Child Neurol Open 2017;4:2329048X17732314.

5. Poojary S, Shah KS, Bhalala KB, Hedge AU. CEDNIK syndrome in an Indian patient with a novel mutation of the SNAP29. Pediatr Dermatol 2019;36:372-376.

6. Tiwana H, Raymond G, Kumar A. CEDNIK syndrome, a rare neuro-cutaneous disorder. Neurology 2019;92:P1.6-050.

7. Llaci L, Ramsey K, Belnap N, et al. Compound heterozygous mutations in SNAP29 is association with Pelizaeus-Merzbacher-like disorder (PMLD). Hum Genet 2019;138: 1409-1417.

8. Abdollahi MR, Morrison E, Sirey T, et al. Mutation of the variant alpha-tubulin TUBA8 results in polymicrogyria with optic nerve hypoplasia. Am J Hum Genet 2009;85:737-744.

9. Diggle CP, Martinez-Garay I, Molnar Z, et al. A tubulin alpha 8 mouse knockout model indicates a likely role in spermatogenesis but not in brain development. PLoS One 2017;12:e0174264.

10. Schiller SA, Seebode C, Wieser GL, et al. Non-keratinocyte SNAP29 influences epidermal differentiation and hair follicle formation in mice. Exp Dermatol 2016;25:647-649.

11. Pan PY, Cai Q Lin L, Lu PH, Duan S, Sheng ZH. SNAP-29-mediated modulation of synaptic transmission in cultured hippocampal neurons. J Biol Chem 2005;280: 25769-25779.

12. Mastodonato V, Beznoussenko G, Mironov A, Ferrari L, Deflorian G, Vaccari T. A genetic model of CEDNIK syndrome in zebrafish highlights the role of the SNARE protein Snap29 in neuromotor and epidermal development. Sci Rep 2019;9:1211.

13. Keser V, Lachance JB, Alam SS, et al. Snap29 mutant mice recapitulate neurological and ophthalmological abnormalities associated with CEDNIK syndrome. Commun Biol 2019;2:375

14. Toomes C, Jackson A, Maguire K, et al. The presence of multiple regions of homozygous deletion at the CSMDI locus in oral squamous cell carcinoma question the role of CSMDI in head and neck carcinogenesis. Genes Chromosomes Cancer 2003;37: $132-140$.

15. Pagnamenta AT, Howard MF, Wisniewski E, et al. Germline recessive mutatiosin PI4KA are associated with perisylvian polymicrogyria, cerebellar hypoplasia, and arthrogryposis. Hum Mol Genet 2015;24:3732-3741.

16. Heparin cofactor II; HCF2. In: Online Mendelian Inheritance in Man. Available at: omim.org/entry/142360?search=serpind1\&highlight=serpind1. Accessed April 19, 2020.

17. Zhang Y, Shi J, Wei H, Han V, Zhu WZ, Liu C. Neonate and Infant brain development from birth to 2 years assessed using MRI-based quantitative susceptibility mapping. Neuroimage 2019;185:349-360.

18. McDonald-McGinn DM, Fahiminiya S, Revil T, et al. Hemizygous mutations in SNAP29 unmask autosomal recessive conditions and contribute to atypical findings in patients with 22q11. 2DS. J Med Genet 2013;50:80-90.

19. GTEx portal: Gene expression for SNAP29 from GTEx analysis Release V8. The broad Institute. Available at: gtexportal.org/home/gene/ENSG00000099940. Accessed April 19, 2020.

20. Kearse MG, Wilusz JE. Non-AUG translation: a new start for protein synthesis in eukaryotes. Genes Dev 2017;31:1717-1731.

21. Schardt A, Brinkmann BG, Mitkovski M, Sereda MW, Werner HB, Nave KA. The SNARE protein SNAP-29 interacts with the GTPase Rab3a: Implications for trafficking in myelinating glia. J Neurosci Res 2009;87:3465-3479.

22. Dubois J, Dehaene-Lambertz G, Kulikova S, Poupon C, Hüppi PS, Hertz-Pannier L. The early development of brain white matter: a review of imaging studies in fetuses, newborns, and infants. Neuroscience 2014;276:48-71. 


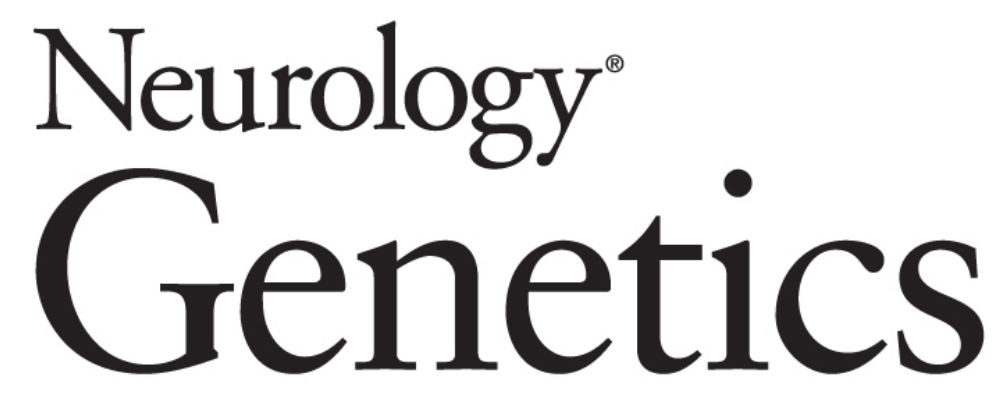

\section{New Cohort of Patients With CEDNIK Syndrome Expands the Phenotypic and Genotypic Spectra}

Annelise Y. Mah-Som, Cristina Skrypnyk, Andrea Guerin, et al.

Neurol Genet 2021;7;

DOI 10.1212/NXG.0000000000000553

This information is current as of January 12, 2021

\section{Updated Information \&} Services

References

Subspecialty Collections

Permissions \& Licensing

Reprints including high resolution figures, can be found at: http://ng.neurology.org/content/7/1/e553.full.html

This article cites 20 articles, 2 of which you can access for free at: http://ng.neurology.org/content/7/1/e553.full.html\#\#ref-list-1

This article, along with others on similar topics, appears in the following collection(s):

All Genetics

http://ng.neurology.org//cgi/collection/all_genetics

Developmental disorders

http://ng.neurology.org//cgi/collection/developmental_disorders MRI

http://ng.neurology.org//cgi/collection/mri

Information about reproducing this article in parts (figures,tables) or in its entirety can be found online at:

http://ng.neurology.org/misc/about.xhtml\#permissions

Information about ordering reprints can be found online: http://ng.neurology.org/misc/addir.xhtml\#reprintsus

Neurol Genet is an official journal of the American Academy of Neurology. Published since April 2015, it is an open-access, online-only, continuous publication journal. Copyright Copyright $\odot 2021$ The Author(s). Published by Wolters Kluwer Health, Inc. on behalf of the American Academy of Neurology.. All rights reserved. Online ISSN: 2376-7839.

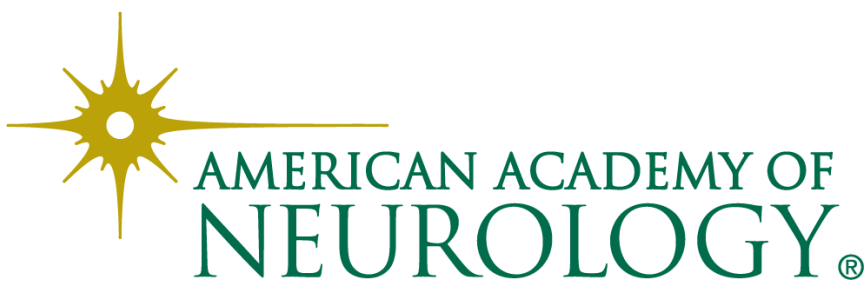

